\title{
Body size, reproductive biology and abundance of the rare pseudoboini snakes genera Clelia and Boiruna (Serpentes, Colubridae) in Brazil
}

\author{
Lígia Pizzatto \\ Departamento de Zoologia, Instituto de Biologia, Universidade Estadual de Campinas, CP 6109, 13083-970, \\ Campinas, SP, Brazil. E-mail: ligia_oceanica@yahoo.com.
}

\begin{abstract}
Body size, reproductive biology and abundance of the rare pseudoboini snakes genera Clelia and Boiruna (Serpentes, Colubridae) in Brazil. Pseudoboini snakes of the genera Clelia and Boiruna are apparently rare in nature and certainly rare in collections. This work presents data on body size, reproduction and abundance of five Brazilian species of these genera, in the largest collection of snakes in Latin America, the Instituto Butantan. Despite scarcity of data, follicular cycle seems to be continuous in most species, except Clelia rustica, which occurs in highlands. Females are larger than males in all species, and fecundity is low when compared to other pseudoboini. Abundance is very low for all species even considering 100 years of collecting, and it is decreasing in recent decades when compared to other snakes (Bothrops jararaca, Oxyrhopus guibei, O. clathratus, Philodryas patagoniensis, Sibynomorphus mikanii, and Spilotes pullatus). The studied species present at least five traits of commonly threatened species and require more attention in researches and conservation policies.
\end{abstract}

Keywords: Serpentes, Colubridae, Clelia, Boiruna, abundance, body size, conservation, reproduction.

\section{Introduction}

Diversity of snake species in the Neotropics is enormous. Gathering detailed ecological data based on field observations of habitat use, behavior, and temporal variation in population sizes for each species in highly diverse communities is a daunting task, unlikely to be completed soon (Reed and Shine 2002). Populational studies are virtually absent for any species and despite availability of some studies on

Received 15 August 2005.

Accepted 21 November 2005.

Distributed December 2005. communities for some areas (Duellman 1978, Vitt and Vangilder 1983, Dixon and Soini 1986, Strussmann 1992, Martins 1994, Marques 1998, Sawaya 2003), the populational status and abundance of most species are largely unknown. This lack of general and specific knowledge places us far from realistic conservation policies. In sharp contrast to field work with snakes, studies on ecological attributes based on data from preserved museum specimens offer a good opportunity to quantify many life history traits to a degree not yet possible for most reptiles (Reed and Shine 2002).

Reproductive cycles of snakes can be seasonal even in tropical areas (Shine 2003). Studies 
on the reproduction of Neotropical snakes are still scarce but most oviparous species lay eggs in the late rainy season and hatchings occur in the early dry season (Marques 1996a, Fowler et. al. 1998, Marques and Puorto 1998, Hartmann et al. 2002, Marques 2002, Pinto and Fernandes 2004).

Colubridae is the most studied family of snakes in Neotropical areas. However, it is the largest family and constitutes an unnatural group, containing many unrelated species (Heise et al. 1995). Many monophyletic clades in this family, like the pseudoboini tribe, are unstudied, even documenting basic information such as body size and reproduction.

The pseudoboini snakes of the genera Boiruna and Clelia are commonly known as "mussuranas" in Brazil. The genus Boiruna comprises two species: Boiruna maculata (previously Clelia occipitolutea) and Boiruna sertaneja (Zaher 1996). The genus Clelia comprises ten species (Morato et al. 2003): C. clelia, C. plumbea, C. quimi, C. montana, C. rustica, C. bicolor, C. hussami, C. equatoriana, C. scytale, and C. errabunda. Both genera occur in South America and Clelia clelia is also found in Mexico (for detailed distribution see Bailey 1970, Scrocchi and Viñas 1990, Zaher 1996, Franco et al. 1997).

Snakes of genera Boiruna and Clelia are rarely found in the field, in spite of their medium to large size. Thus, they are not abundant in collections, even in large ones such as that of the Instituto Butantan, in São Paulo State. These snakes frequently show ontogenetic shifts in color pattern in which juveniles have a coral snake pattern (generally reddish with white collar and black dorsal stripes) and adults have a dark color pattern (for a detailed description see Zaher 1996 and Franco et al. 1997). In terms of reproduction, the only pseudoboini species studied is the false coral snake Oxyrhopus guibei, which reproduces continuously (Pizzatto and Marques 2002). Considering that this tribe is monophyletic (Zaher 1994) and that there are some phylogenetic patterns in reproduction (Vitt
1987, Shine 1989, Marques 1996a, b, 1998), it was logical to expect that species of Clelia and Boiruna could reproduce throughout the year. However, this is doubtful since these snakes are rare and it could be, at least in part, due to reproduction. A more obvious expectation is that at least largest species must present a high fecundity.

This work presents data on body size, sexual dimorphism and reproduction in Boiruna maculata, Clelia clelia, C. plumbea, C. rustica, C. quimi and C. montana, detecting similarities and differences among species and comparing them to Oxyrhopus guibei. I also present data on seasonal reception of these snakes in the Instituto Butantan collection compared to other species. I make inferences regarding their population status, relating life history traits with their apparent rarity.

\section{Material and Methods}

The examined specimens of Boiruna maculata, C. plumbea, C. quimi and C. montana were collected mainly in southeastern Brazil, São Paulo State (19.7 - 25.3 S, 44.2 - 53.2 $\left.{ }^{\circ} \mathrm{W}\right)$, where climate is seasonal, with a hot and rainy spring-summer (October to March) and a dry autumn-winter (April to September). However, C. montana occurs in highland areas where autumn-winter is more rigorous and springsummer is milder. Clelia rustica specimens were collected in south Brazil (from 22.5 - 33. $7^{\circ} \mathrm{S}$, $48.2-57.6^{\circ} \mathrm{W}$ ), where climate is also seasonal but with a mild and dry spring-summer (October to March) and cold and rainy autumn-winter (April to September). Clelia clelia were collected mostly in the Amazon domain (4.4 $\left.21.2^{\circ} \mathrm{S}, 45.7-73.6^{\circ} \mathrm{W}\right)$, where temperatures are high throughout the year but a dry season occurs in the winter (July to September).

I examined 107 individuals of Boiruna maculata (17 females, 34 males and 56 juveniles - juveniles are non-mature snakes, see below), 68 individuals of Clelia plumbea (23 females, 10 males and 35 juveniles), 21 indivi- 
duals of Clelia clelia (4 females, 8 males and 9 juveniles), 28 individuals of Clelia rustica (16 females, 8 males and 4 juveniles), 30 individuals of Clelia quimi (10 females, 14 males and 6 juveniles) and seven individuals (3 males and 4 juveniles) of Clelia montana from the collections of Museu de História Natural do Capão da Imbuia (MHNCI), Museu de História Natural da Universidade Estadual de Campinas (ZUEC) and Instituto Butantan (IB). Each specimen was measured for snout-vent length (SVL in mm, with a ruler), sexed, and dissected by a mid ventral incision. With a vernier caliper I measured: (1) diameter of the largest follicle or oviductal egg (when eggs were present all of them were measured in length and width), (2) length, width and thickness of both testes and (3) diameter of deferent duct near the cloaca. Females were considered mature if they had vitellogenic follicles larger than $10 \mathrm{~mm}$, oviductal eggs or folded oviducts (Shine 1978). Males were mature if they had turgid testes or opaque and convoluted deferent ducts (Shine 1980a, Slip and Shine 1988). Testes volume, which reflects testicular activity (Volsøe 1944, pers. obs.), were calculated using the ellipsoid formula $(4 / 3 \pi \mathrm{abc})$, where $\mathrm{a}=$ length $/ 2, \mathrm{~b}=$ width/2 and $\mathrm{c}=$ thickness/2 (Pleguezuelos and Feriche 1999). Oviductal eggs and vitellogenic follicles were counted to estimate fecundity.

I analyzed snout-vent length differences among species and between sexes using factorial ANOVA with SVL as the dependent variable, sex and species as factors and a Post-hoc Tukey test (Zar 1999).

Testes volume and deferent duct diameter were significantly related to SVL. Thus, variation in testicular volume and diameter of deferent duct were compared among seasons by ANCOVA, using testes volume and deferent duct diameter as dependent variable, season as factor and SVL as continuous variable (Zar 1999).

Clutch size was compared among the studied species and Oxyrhopus guibei using linear regression of clutch size by female SVL for all species together and calculating its residuals.
Then, residuals for each species were compared by Kruskal-Wallis test (Zar 1999). Data for $O$. guibei were obtained from Pizzatto and Marques (2002). Reproductive frequency was estimated by the percentage of reproductive females (with ovarian follicles $>10 \mathrm{~mm}$ or oviductal eggs) in each sample (Seigel and Ford 1987).

I inferred species activity by the number of preserved snakes in collections by month. I compared the number of snakes for each species among four seasons (Summer, Autumn, Winter and Spring) using Chi-squared test (Zar 1999). I also recorded the number of individuals of the studied species that arrived at Instituto Butantan during each decade between 1917 and 2004. The number of snakes (abundance) by decade was compared using Chi-squared test (Zar 1999).

\section{Results}

\section{Body Size}

There were only three mature males of Clelia montana (SVL 762, 661 and $635 \mathrm{~mm}$, respectively) in the sample and it was not included in body size analyses.

Females attained larger SVL than males in all species (factorial ANOVA, $F_{(s e x)}=28.4, p<$ 0.01 ), except $C$. clelia (Table 1 ). There were significant differences in body size among species (factorial ANOVA, $F_{\text {(species) }}=51.9, p<$ $\left.0.01 ; F_{\text {(interation) }}=3.56, p<0.01\right)$. Clelia quimi was the smallest species and $C$. plumbea the largest (Table 1). Clelia plumbea differed significantly from Boiruna maculata (females: $p$ $<0.01$, males: $p<0.01$ ), C. quimi (both females and males: $p<0.01$ ) and $C$. rustica (females: $p$ $<0.01$, males: $p<0.01$ ). Clelia quimi differed also from $B$. maculata (females: $p<0.01$, males: $p<0.01$ ) and C. clelia (females: $p<$ 0.01, males: $p<0.01)$. Clelia rustica also differed from $C$. clelia (females: $p<0.01$, males: $p<0.01$ ) (Table 1).

Sexual size dimorphism was greatest in $C$. plumbea and it was similar in the other four 
Table 1 - Body size in five adult Pseudoboinae snakes genera Clelia and Boiruna. All measures in mm, SD = standard deviation. Significant results $(\mathrm{p}<0.05)$ are in bold letters.

\begin{tabular}{|c|c|c|c|c|c|c|c|c|c|c|}
\hline & \multicolumn{2}{|c|}{ Boiruna maculata } & \multicolumn{2}{|c|}{ Clelia rustica } & \multicolumn{2}{|c|}{ Clelia plumbea } & \multicolumn{2}{|c|}{ Clelia quimi } & \multicolumn{2}{|c|}{ Clelia clelia } \\
\hline & 9 & 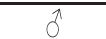 & 9 & $\hat{0}$ & $q$ & $\hat{0}$ & $q$ & $\hat{0}$ & 9 & 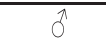 \\
\hline Mean SVL & 1221.6 & 1079.1 & 1139 & 952.4 & 2004.5 & 1146.2 & 886.6 & 725 & 1632.2 & 1348.6 \\
\hline SD & 143.4 & 178.2 & 97.97 & 147.9 & 430.6 & 322.0 & 148.1 & 95.4 & 295.8 & 347.9 \\
\hline Range & $990-1467$ & $745-1465$ & $1000-1850$ & $750-1195$ & $1194-2790$ & $1035-2240$ & $660-1078$ & $573-884$ & $1372-2028$ & $650-1763$ \\
\hline $\mathrm{N}$ & 17 & 32 & 16 & 8 & 23 & 10 & 10 & 14 & 4 & 8 \\
\hline t-test & \multicolumn{2}{|c|}{$\mathrm{t}=2.84, \mathrm{p}<0.01$} & \multicolumn{2}{|c|}{$\mathrm{t}=2.48, \mathrm{p}<\mathbf{0 . 0 5}$} & \multicolumn{2}{|c|}{$t=-3.66, p<0.01$} & \multicolumn{2}{|c|}{$t=3.26, p<0.01$} & \multicolumn{2}{|c|}{$\mathrm{t}=1.39, \mathrm{p}>0.05$} \\
\hline SSD & \multicolumn{2}{|c|}{0.13} & \multicolumn{2}{|c|}{0.17} & \multicolumn{2}{|c|}{0.75} & \multicolumn{2}{|c|}{0.22} & \multicolumn{2}{|c|}{0.21} \\
\hline
\end{tabular}

species (Table 1). Females of most species attain sexual maturity at $80-88 \%$ of mean adult body size, except to C. plumbea and C. quimi, which mature with smaller sizes (50\% and $74 \%$ ). In general, males attain sexual maturity with smaller body sizes than females but the ratio is more variable, from $48 \%$ in C. clelia to $90 \%$ in C. plumbea (see minimum sizes in Table 1).

\section{Reproductive Cycles and Recruitment}

Boiruna maculata: vitellogenic follicles were found in July, August, October and February, while eggs were present in May, August, September and December (Figure 1A). Small snakes (SVL $<400 \mathrm{~mm}$ ) were found from December to June, with a peak from March to June (Figure 2A). Testicular volume did not differ among seasons (ANCOVA: $F_{\text {(slopes) }}=1.27$, $g l=3, p>0.05, F_{\text {(intercept) }}=0.61, \stackrel{g l}{g l}=3, p>$ $0.05)$ as well as residual diameter of deferent duct (ANCOVA: $F_{\text {(slopes) }}=2.87, g l=3, p>0.05$,

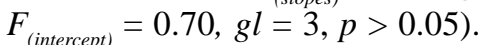

Clelia plumbea: vitellogenic follicles were found throughout the year (Figure 1B) as well as small snakes (SVL $<500 \mathrm{~mm}$ ). A larger number of small snakes was collected in May, July and October (Figure 2B).

Clelia clelia: none of sampled females had vitellogenic follicles or eggs and the smallest snake measured $466 \mathrm{~mm}$ (September), $480 \mathrm{~mm}$ (no data) and $493 \mathrm{~mm}$ (December) in SVL.

Clelia rustica: vitellogenic follicles were found in January, March, November and December. One egg occurred in December (Figure 1C) and only one young (probably newborn, SVL = $267 \mathrm{~mm}$ ) was sampled in March.

Clelia quimi: vitellogenic follicles were found in July and eggs in September and October (Figure 1D). Two very small snakes (SVL = 215 and $226 \mathrm{~mm}$,) were found in February, one in March (SVL = $238 \mathrm{~mm}$ ), one in April $(\mathrm{SVL}=260 \mathrm{~mm})$ and one in May $(\mathrm{SVL}=$ $333 \mathrm{~mm})$.

Clelia montana: only three young (probably newborn) were collected in April (SVL = 276 $\mathrm{mm})$, May (SVL $=275 \mathrm{~mm}$ ) and December $(\mathrm{SVL}=265 \mathrm{~mm})$.

\section{Fecundity}

When all species were considered together, clutch size increased with female SVL $\left(R^{2}=\right.$ $0.44, \beta=0.008, p<0.01$, Figure 3). Clutch size differed among species of Boiruna and Clelia $\left(H_{(3,22)}=13.89, p<0.01\right)$ and also with $O$. guibei $\left(H_{(4,61)}=17.04, p<0.01\right.$, Figure 3$)$. Clelia quimi (and also O. guibei) had the largest clutch size and $C$. plumbea the smallest (Figure 3, Table 2). Egg size was smaller in C. quimi than in B. maculata (Table 2) and it is probably due to differences in body size of the species. Reproductive frequency was $53 \%$ in C. clelia, $56 \%$ in C. rustica, $50 \%$ in C. plumbea and $40 \%$ in C. quimi (i.e. only half of adult females are reproducing each year). 

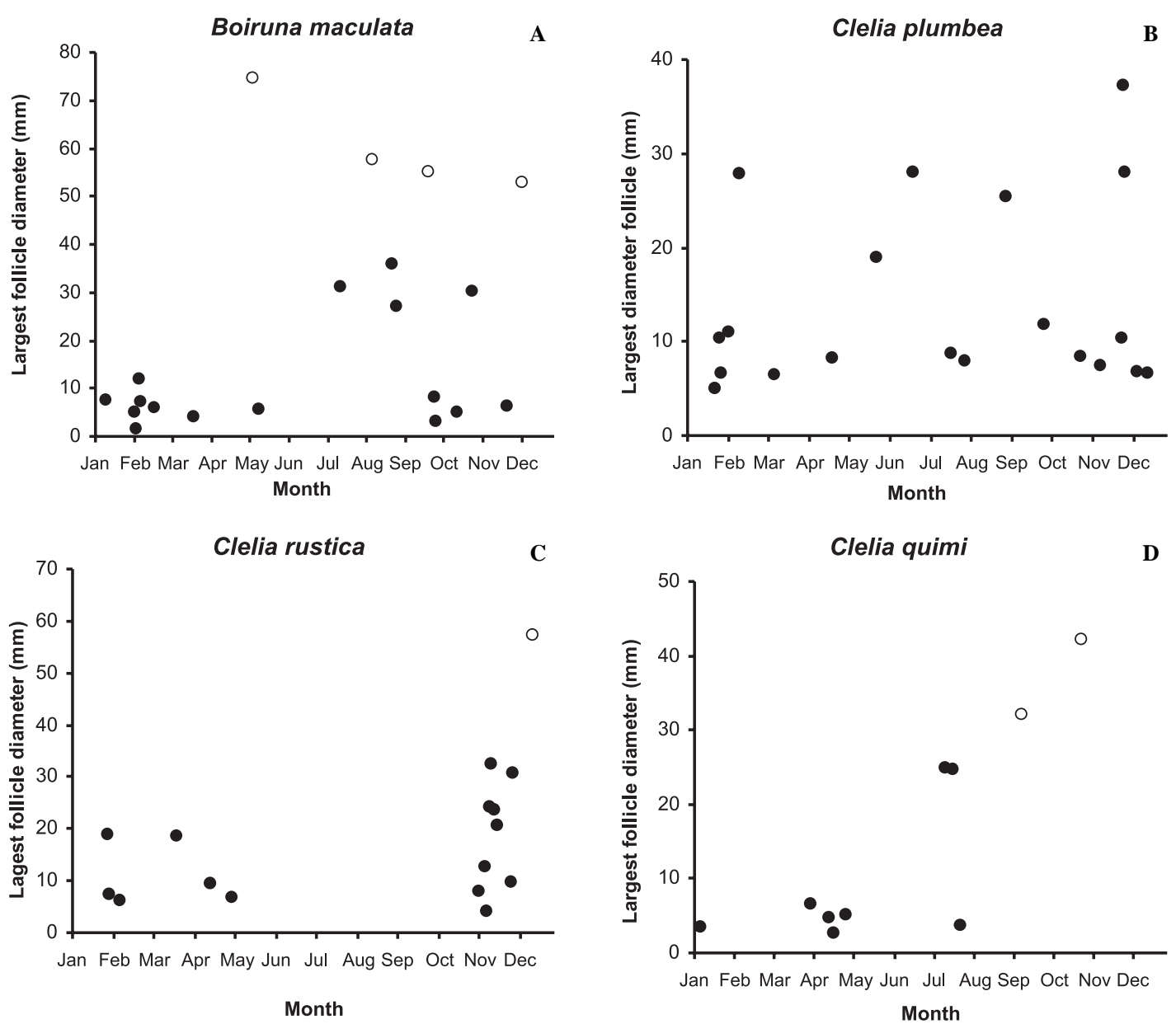

Figure 1 - Seasonal distribution of vitellogenic follicles (dark circles) and eggs (white circles) in pseudoboinae snakes genera Boiruna (A) and Clelia (B-D) from Brazil.

A

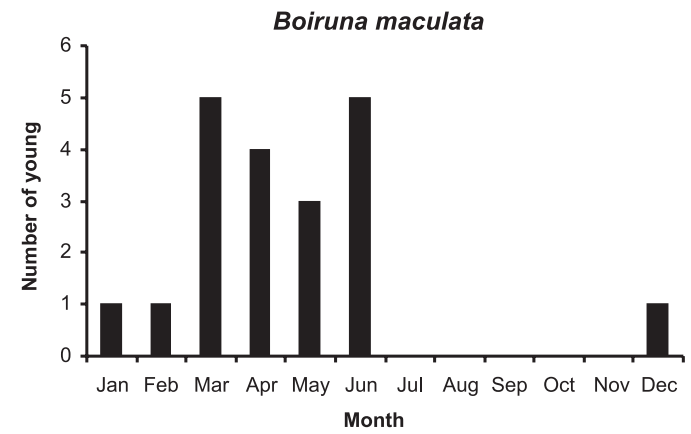

B

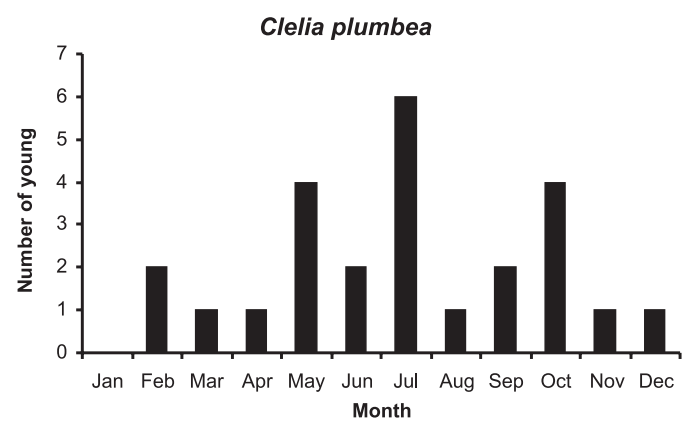

Figure 2 - Number of young in Pseudoboinae snakes genera Boiruna (A) and Clelia (B) from Brazil. 


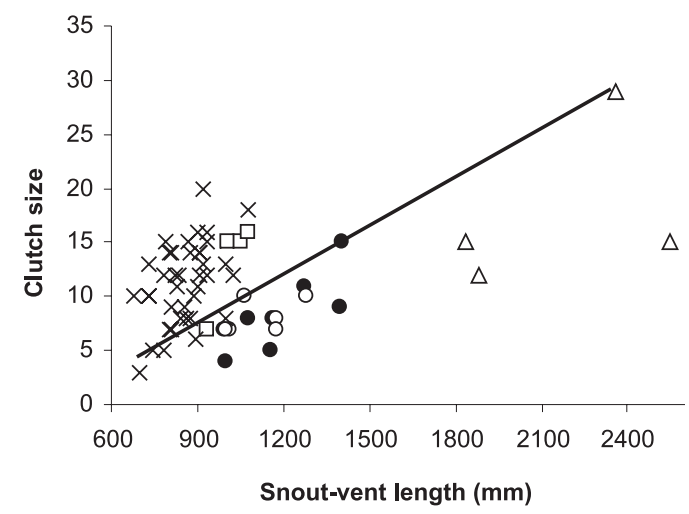

Figure 3 - Fecundity in Pseudoboinae snakes genera Boiruna and Clelia from Brazil. Dark circles: Boiruna maculata, white circles: Clelia rustica, triangles: Clelia plumbea, squares: Clelia quimi, X: Oxyrhopus guibei.

\section{Activity}

Sample sizes for male and female Clelia clelia and C. montana were too small; data on activity for these species are not presented.

Boiruna maculata: number of females did not vary among seasons $\left(\chi^{2}=3.94, d f=3, p>\right.$ 0.05 , Figure 4A). Although number of males also did not vary $\left(\chi^{2}=6.29, d f=3, p>0.05\right)$, they were more abundant in April and May compared to other months $\left(\chi^{2}=14.06, d f=1\right.$, $p>0.05$, Figure 4A).

Clelia plumbea: there were no differences in number of females $\left(\chi^{2}=20.00, d f=3, p>0.05\right)$ among seasons. Male samples were too small $(\mathrm{N}=8)$.

Clelia rustica: although small sample size, females were collected more during November to December $\left(\chi^{2}=23.74, d f=1, p<0.01\right)$ and male samples were too small (Figure 4B).

Clelia quimi: there were no differences in number of females $\left(\chi^{2}=3.60, d f=3, p>0.05\right)$ or males $\left(\chi^{2}=1.43, d f=3, p>0.05\right.$, Figure 4C) among seasons.

\section{Number of Snakes Received at Instituto Butantan}

Snakes of genera Boiruna and Clelia were rarely collected before 1960 when a large increase was recorded (Figure 5A). After the 1960s, the number of snakes decreased and dropped to 39 from 1994 to 2004. Boiruna maculata is the most abundant species, followed by $C$. plumbea and C. quimi . Clelia montana is the rarest species with only six specimens recorded in total. Number of collected snakes is greatest from 1961 to 1971 and least from 1994 to 2004 for B. maculata $\left(\chi^{2}=27.9, d f=3, p<\right.$ $0.01)$, Clelia clelia $\left(\chi^{2}=26.0, d f=3, p=0.028\right)$, C. plumbea $\left(\chi^{2}=39.7, d f=3, p<0.01\right), C$. bicolor $\left(\chi^{2}=8.4, d f=3, p=0.038\right)$ and $C$. quimi $\left(\chi^{2}=27.2, d f=3, p<0.01\right)$ (Figure 5A). Number of collected snakes of $C$. rustica did not vary among these periods $\left(\chi^{2}=5.2, d f=3, p>\right.$ $0.05)$. The decrease in number of snakes

Table 2 - Fecundity parameters of four pseudoboini snakes genera Boiruna and Clelia. Clutch size: mean \pm standard deviation. Significant results are in bold letters.

\begin{tabular}{lcccc}
\hline & Boiruna maculata & Clelia plumbea & Clelia rustica & Clelia quimi \\
\hline Clutch size (\# eggs) & $8.4 \pm 3.5(4-15)[8]$ & $17.7 \pm 7.6(12-29)[4]$ & $8.2 \pm 1.5(7-10)[6]$ & $13.2 \pm 4.2(7-26)[4]$ \\
SVL x clutch size & $\mathrm{R}^{2}=0.59, \beta=0.06$, & $\mathrm{R}^{2}=0.21, \beta=0.01$, & $\mathrm{R}^{2}=0.21, \beta=0.006$, & $\mathrm{R}^{2}=0.83, \beta=0.061$, \\
& $\mathbf{p}<\mathbf{0 . 0 5}$ & $\mathrm{p}>0.05$ & $\mathrm{p}>0.05$ & $\mathrm{p}>0.05$ \\
Egg length $(\mathrm{mm})$ & $45.8 \pm 8.1[35]$ & - & - & $31.7 \pm 4.7[23]$ \\
Egg width $(\mathrm{mm})$ & $19.7 \pm 3.9[35]$ & & & $17.1 \pm 2.9[23]$ \\
\hline
\end{tabular}



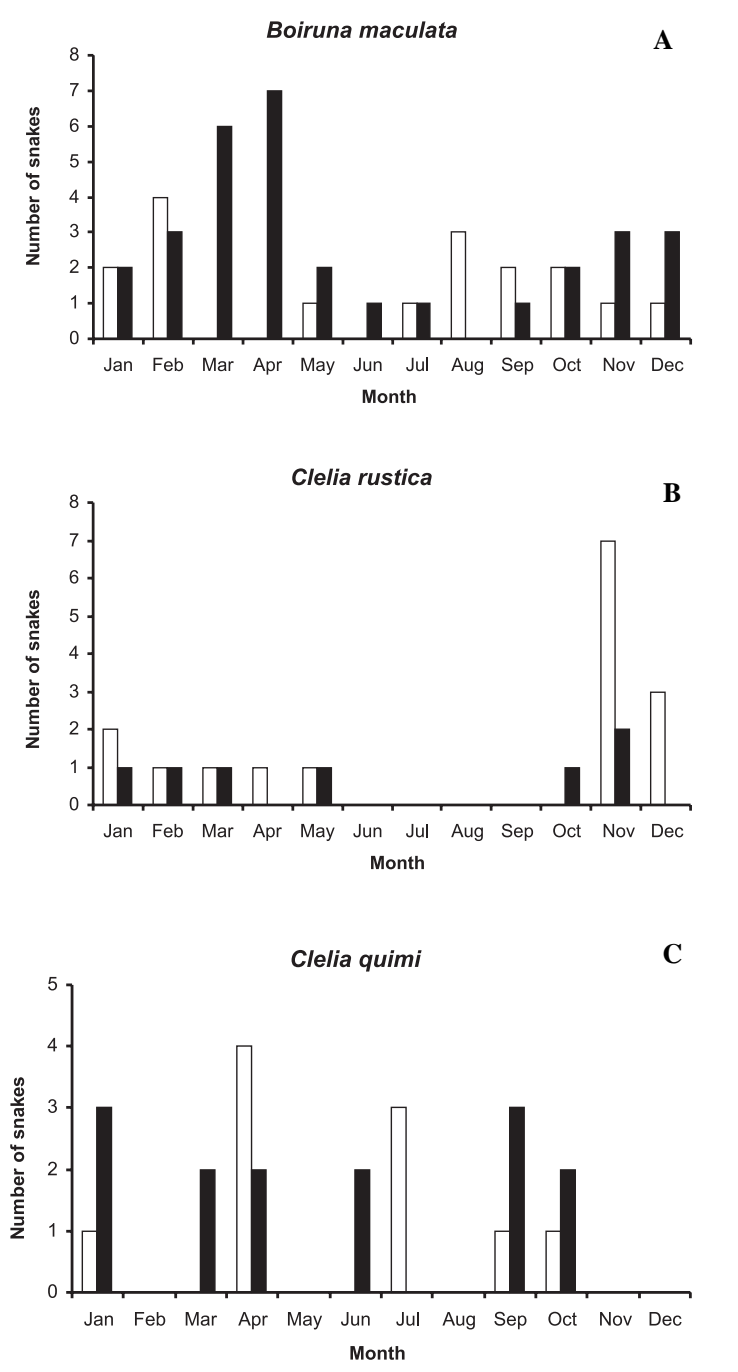

Figure 4 - Seasonal abundance of males (dark bars) and females (white bars) in Pseudoboinae snakes genera Boiruna and Clelia from Brazil.

collected after 1972 is not seen in other species, including two pseudoboini of the genus Oxyrhopus (Figure 5B).

\section{Discussion}

Female reproductive cycles are continuous in Boiruna maculata and Clelia plumbea, similar to Oxyrhopus guibei (Pizzatto and Marques 2002). In the other species, the small sample size makes this affirmation uncertain. There are many phylogenetic trends in reproductive patterns of snakes, with most species in the same monophyletic clade exhibiting the same reproductive timing. This trend was observed in Boinae snakes (pers. obs.), Xenodontini (Jordão 1996, Marques 1996a, Pizzatto 2003, Pinto and Fernandes 2004), coral snakes (genus Micrurus; Marques et al. 2003) and in pitvipers (Bothrops; Almeida-Santos and Salomão 2002, Nogueira $e t$ al. 2003, Hartmann et al. 2004). Probably, the genus Clelia is not monophyletic and many species in this genus seem to be more closely related to Pseudoboa (Zaher 1994). Moreover, C. quimi and C. rustica may belong to a clade unrelated with Clelia and Boiruna. On the other hand, climate can also affect reproduction (Seigel and Ford 1987) and the same species can present continuous cycle in warmer areas but seasonal pattern in colder areas (see Jordão 1996 for Waglerophis merremii, Maciel 2002 and Pizzatto 2003 for Liophis miliaris, Pinto and Fernandes 2004 for Liophis poecilogyrus). Considering climatic influence, it is more probable that species such as Clelia rustica and Clelia montana, which occur in cold areas - i.e., southwards and highlands areas, respectively present a seasonal pattern. In this case, egglaying should occurs in the spring and hatchlings in late summer to early autumn. Thus, eggs can incubate in higher temperatures (in springsummer) avoiding low temperatures and possible abnormal embryologic development (Vinegar 1977).

Male cycle is more difficult to access. Although some tropical snakes have seasonal testicular cycles (Seigel and Ford 1987, Almeida-Santos and Salomão 2002), sperm production is commonly cheaper than egg production and continuous cycles are also expected in tropical areas (Fitch 1982, SaintGirons 1982, Vitt 1983, Seigel and Ford 1987). Boiruna maculata, as well as Oxyrhopus guibei (Pizzatto and Marques 2002), have continuous 

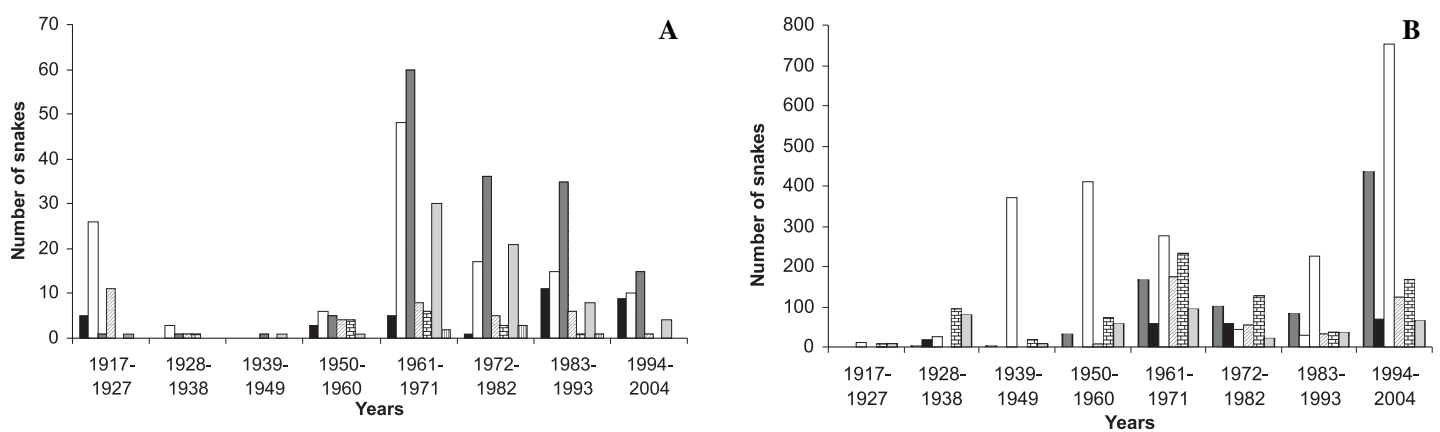

Figure 5 - Seasonal abundance of (A) Pseudoboinae snakes genera Boiruna and Clelia and (B) other snakes from 1917 to 2004. (A) Black bars: Clelia clelia, white: C. plumbea, diagonal stripes: Boiruna maculata, dotted: C. rustica, horizontal stripes: C. bicolor, grey: C. quimi and vertical stripes: C. montana. (B) Black bars: Oxyrhopus clathratus, white: Bothrops jararaca, diagonal stripes: Philodryas patagoniensis, dotted: Sibynomorphus mikanii, horizontal stripes: Spilotes pullatus, grey: Oxyrhopus guibei.

sperm production and it may occurs in other pseudoboini such as Clelia spp.

Reproductive events may influence snake activity (Shine 1979, Marques et al. 2001). Despite the possibility of some bias in the searching effort throughout the year that can occur in collections, the number of snakes per season can be a good indicative of their activity (Shine 1980a, Marques et al. 2001). Frequently, males are more exposed to collection during the breeding season when they are more active looking for females (Duvall et al. 1992). More males Boiruna maculata are collected in April and May compared to other months; thus, it is possible that this species mates in autumn. More female Clelia rustica are collected in November-December when they have oviductal eggs. Gravid snakes tend to increase thermoregulation time, are more active searching for sites for oviposition, and are slower than non-gravid (Shine 1979, 1980b, Seigel et al. 1987) being more susceptible for collection.

This study showed that members of the pseudoboini genera Boiruna and Clelia have the potential to reproduce continuously. Snakes from these genera seem to be uncommon and rare in nature (Marques et al. 1998) even when compared to other pseudoboini such as Oxyrho- pus guibei (Pizzatto and Marques 2002). Despite the generalist diet (Amaral 1978, Vitt and Vangilder 1983, Pinto and Lema 2002, Teixeira and Vrcibradic 2003) and continuous reproduction, most species (at least those occurring in warmer areas) exhibit a low fecundity, in terms of relative clutch size and reproductive frequency, when compared to Oxyrhopus guibei. Low clutch size is unexpected in large species such as Boiruna maculata, Clelia plumbea and Clelia clelia. Rarity is largely affected by reproductive traits (McArthur and Wilson 1967, Kunin and Gaston 1993) and so, the low fecundity and late maturity of adults (large SVL) can be a factor contributing to low abundance of the studied species.

The oldest specimen analyzed in this study was a Boiruna maculata collected in 1917. Even considering a sample of 90 years of collecting and receiving of snakes, all species together totaled 436 individuals, and most species have a very small sample size. Considering reception of these pseudoboini snakes through the whole existence of the Institute Butantan, the maximum numbers recorded from 1961 to 1971 can be due a high incentive campaign for snake collection those years and can be also seen in other snakes (Figure 5B). However, in the 
following ten years, the reception of Clelia and Boiruna species decreased considerably and reached a minimum from 1994 to 2004, even with snakes rescued from a hydroelectric flooding occurred at this decade. During this rescue, only one Clelia quimi was collected. This decrease is not recorded for species such as Bothrops jararaca, Oxyrhopus guibei, O. clathratus, Philodryas patagoniensis, Sibynomorphus mikanii or Spilotes pullatus (Figure 5B). Thus, numbers of these species are decreasing through the years, possibly due to populational decrease in nature. Reception of Clelia montana has been very low since the founding of the Institute. This low abundance probably is related to their restricted distribution in highlands (Franco et al. 1997).

None of the studied species are in the IUCN red list or local red lists due to absence of information for evaluation. However, there are several traits that increase risk of extinction, such as low abundance (Pimm et al. 1988, 1993, Mace and Kershaw 1997), small range size (Gaston 1994, Hanski et al. 1996, Manne et al. 1999), habitat specialization (Brown 1995), proximity to locations of high human density, large body size (McKinney 1997, Owens and Bennett 2000), geographic location (Ariño and Pimm 1995, Manne et al. 1999), higher trophic level (Primack 1993, Gaston and Kunin 1997, Manne and Pimm 2001) and "slow" life histories (small litters, slow growth, late maturation, long inter birth intervals and high survival rates) (MacArthur and Wilson 1967, Pimm 1991, Purvis et al. 2000, Webb et al. 2002, Pilgrim et al. 2004). Larger size of females in relation to males, absence of combat, ambush feeding behavior (Reed and Shine 2002) and "slow" life histories (Webb et al. 2002) may make snakes more vulnerable to extinction. Species of Clelia and Boiruna apparently have at least five (low abundance, "slow" life-history - low fecundity and possibly late maturation due to the large size of maturation - larger body size, higher trophic level, females larger than males and absence of combat) of these traits, which suggest that they deserve more attention in research and conservation policies.

\section{Acknowledgements}

I am very thankful to Valdir J. Germano (IB) and Renato Bérnils (MHNCI) for assistance in laboratory, Ivan Sazima and Paulo R. Manzani (ZUEC), Francisco L. Franco (IB) and Julio C. Moura-Leite (MHNCI) for providing access to the collections, Fernanda S. de Oliveira for providing accommodation during the visit to MHNCI, Valdir J. Germano and Francisco L. Franco for help in identifying the specimens, Otavio A. V. Marques and two anonymous referees for manuscript review. This work was supported by FAPESP.

\section{References}

Amaral, A. 1978. Serpentes do Brasil: iconografia colorida. $2^{\text {nd }}$ ed. São Paulo. Editora da Universidade de São Paulo.

Ariño, A. and S. Pimm. 1995. On the nature of population extremes. Evolutionary Ecology 9: 429-443.

Almeida-Santos, S. M. and M. G. Salomão, 2002. Reproduction in Neotropical pitvipers, with emphasis on species of the genus Bothrops. Pp. 442-562 in G. W. Schuett, M. Höggren, M. E. Douglas, and H. W. Greene (eds.), Biology of the Vipers. Eagle Mountain Publishing. Eagle Mountain.

Bailey, J. R. 1970. Clelia. Pp. 62-64 in J. A. Peters and B. Orejas-Miranda (eds.). Catalogue of the Neotropical Squamata: Part I. Snakes. Washington DC and London. Smithsonian Institution Press.

Brown J. H. 1995. Macroecology. University of Chicago Press. Chicago.

Dixon, J. R. and P. Soini. 1986. The Reptiles of the Upper Amazon Basin, Iquitos region, Peru II. Milwakee. Milwaukee Public Museum.

Duellman, W. E. 1978. The biology of an equatorial herpetofauna in Amazonian Ecuador. University of Kansas Museum of Natural History Miscellaneous Publications 65: 1-352.

Duvall, D., S. J. Arnold and G. W. Schuett. 1992. Pitviper mating systems: ecological potential, sexual selection, and microevolution. Pp. 321-336 in J. A. Campbell and E. D Brodie Jr. (eds.), Biology of the Pitvipers. Selva. Tyler. 
Franco, F. L., O. A. V. Marques and G. Puorto. 1997. Two new species of colubrid snakes of the genus Clelia from Brazil. Journal of Herpetology 31: 483-490.

Fitch, H. S. 1982. Reproductive cycles in tropical reptiles. Occasional Papers of the University of Kansas Museum of Natural History 96: 1-53.

Fowler, I. R., M. G. Salomão and R. S. Jordão. 1998. A description of the female reproductive cycle in four species from neotropical colubrid snake Philodryas (Colubridae, Xenodontine). The Snake 28: 71-78.

Gaston K. J. 1994. Rarity. London. Chapman and Hall.

Gaston, K. J. and W.E. Kunin. 1997. Rare-common differences: an overview. Pp. 12-29 in W. E. Kunin and K. J. Gaston (eds.), The Biology of Rarity. London. Chapman and Hall.

Hanski, I., A. Moilanen and M. Gyllenberg. 1996. Minimum viable metapopulation size. The American Naturalist 147: 527-541.

Hartmann, M. T., M. L. Del Grande, M. J. C. Gondim, M. C. Mendes, and O. A. V. Marques. 2002. Reproductive biology of the southern pitviper Bothrops pubescens (Serpentes, Viperidae). Studies on Neotropical Fauna and Environment 37: 111-114.

Heise, P. J., L. R. Maxson, H. G. Dowling, and S. B. Hedges. 1995. Higher-level snake phylogeny inferred from mitochondrial DNA sequences of 12s rRNA and 16s rRNA genes. Molecular Biology and Evolution 12: 259-265.

Jordão, R. S. 1996. Estudo comparativo da alimentação e da reprodução de Waglerophis merremii e Xenodon neuwiedii (Serpentes: Colubridae). M.Sc. Dissertation. Universidade de São Paulo, Brazil.

Kunin, W. E. and K. J. Gaston. 1993. The biology of rarity: patterns, causes and consequences. Trends in Ecology and Evolution 8: 298-301.

MacArthur R. H. and E. O. Wilson. 1967. The Theory of Island Biogeography. Princeton University Press, Princeton.

Mace, G. and M. Kershaw. 1997. Extinction risk and rarity on an ecological timescale. Pp. 130-149 in W. Kunin and K. Gaston (eds.), The Biology of Rarity. London. Chapman and Hall.

Maciel, A. P. 2001. Ecologia e história natural da "cobracapim” Liophis poecilogyrus (Serpentes: Colubridae) no litoral norte do Rio Grande do Sul, Brasil. Unpublished M.Sc. Dissertation. Universidade Federal do Rio Grande do Sul, Brazil.

Manne, L. L., T. M. Brooks and S. L. Pimm. 1999. The relative risk of extinction of passerine birds on continents and islands. Nature 399: 258-261.

Manne, L. L. and S. L.Pimm. 2001. Beyond eight forms of rarity: which species are threatened and which will be next? Animal Conservation 4: 221-229
Marques, O. A. V. 1996a. Biologia reprodutiva da cobracoral Erythrolamprus aesculapii (Colubridae). Revista Brasileira de Zoologia 13: 747-753.

Marques, O. A. V. 1996b. Reproduction, seasonal activity and growth of the coral snake Micrurus corallinus (Elapidae) in the southeastern Atlantic forest in Brazil. Amphibia-Reptilia 17: 277-285.

Marques, O. A. V. 1998. Composição faunística, história natural e ecologia de serpentes da Mata Atlântica, na região da Estação Ecológica Juréia-Itatis, SP. Unpublished Ph.D. Thesis. Universidade de São Paulo, Brazil.

Marques, O. A. V. 2002. Natural history of the coral snake Micrurus decoratus (Elapidae) from the Atlantic forest in southeast Brazil, with comments on possible mimicry. Amphibia-Reptilia 23: 228- 232.

Marques, O. A. V. and G. Puorto. 1998. Feeding, reproduction and growth in the crowned snake Tantilla melanocephala (Colubridae) from southeastern Brazil. Amphibia-Reptilia 19: 311- 318.

Marques, O. A. V., S. M. Almeida-Santos and L. Pizzatto. 2003. Differential reproductive strategies in neotropical coral snakes in the genus Micrurus. 2003 Joint Meeting of Herpetologists and Icthiologists. CD ROM Abstracts. Manaus.

Marques, O. A .V., M. Martins and A. S. Abe. 1998. Estudo diagnóstico da diversidade de répteis do Estado de São Paulo. Pp. 29-38 in R. M. C. Castro (org.), Biodiversidade do Estado de São Paulo - síntese do conhecimento ao final do século XX. Vol. 6: Vertebrados. São Paulo. FAPESP.

Marques, O. A. V., A. Eterovic and W. Endo. 2001. Seasonal activity of snakes in the Atlantic forest in southeastern Brazil. Amphibia-Reptilia 22: 103-111.

Martins, M. 1994. História natural e ecologia de uma taxocenose de serpentes de mata na região de Manaus, Amazônia Central, Brasil. Unpublished Ph.D. Thesis. Universidade Estadual de Campinas, Brazil.

McKinney M. L. 1997. Extinction vulnerability and selectivity: Combining ecological and paleontological views. Annual Review of Ecology and Systematics 28: 495-516.

Morato, S. A. A., F. L. Franco and E. J. Sanches. 2003. Uma nova espécie de Clelia (Serpentes: Colubridae) do sul do Brasil. Phyllomedusa 2: 93-100.

Nogueira, C., R. J. Sawaya and M. Martins. 2003. Ecology of the pitviper, Bothrops moojeni, in the Brazilian Cerrado. Journal of Herpetology 37: 653-659.

Owens, I. P. F. and P. M. Bennett. 2000. Ecological basis of extinction risk in birds: habitat loss versus human persecution and introduced predators. Proceedings of the National Academy of Sciences 97: 12144-12148.

Pilgrim, E. S., M. J. Crawley and K. Dolphin. 2004. Patterns of rarity in the native British flora. Biological Conservation 120: 165-174. 
Body size, reproductive biology and abundance of the rare pseudoboini snakes genera Clelia and Boiruna

Pimm, S. L. 1991. The Balance of Nature. University of Chicago Press, Chicago.

Pimm S. L., H. L. Jones and J. Diamond. 1988. On the risk of extinction. American Naturalist 132: 757-785.

Pimm, S. L., J. M. Diamond, T. M. Reed, G. J. Russell, and J. Verner. 1993. Times to extinction for small populations of large birds. Proceedings of the National Academy of Sciences 90: 10871-10875.

Pinto, R. R. and R. Fernandes. 2004. Reproductive biology and diet of Liophis poecilogyrus (Serpentes, Colubridae) from southeastern Brazil. Phyllomedusa 3: 9-14.

Pinto, C. C. and T. Lema. 2002. Comportamento alimentar e dieta de serpentes, gêneros Boiruna e Clelia (Serpentesm Colubridae). Iheringia, Série Zoologia 92: 9-19.

Pizzatto, L. 2003. Reprodução de Liophis miliaris (Serpentes: Colubridae) no Brasil: influência histórica e variações geográficas. Unpublished M.Sc. Dissertation. Universidade Estadual de Campinas, Brazil.

Pizzatto, L. and O. A. V. Marques. 2002. Reproductive biology of the false coral snake Oxyrhopus guibei (Colubridae) from southeastern Brazil. AmphibiaReptilia 23: 495-504.

Pleguezuelos, J. M. and M. Feriche. 1999. Reproductive ecology of the horseshoe snake (Coluber hippocrepis) in the Iberian Peninsula. Journal of Herpetology 33: 202-207.

Primack, R. B. 1993. Essentials of Conservation Biology. Sunderland. Sinauer Associates.

Purvis, A., J. L. Gittleman, G. Cowlishaw, and G. Mace. 2000. Predicting extinction risk in declining species. Proceedings of the Royal Society of London, Series B 267: 1947-1952.

Reed, R. N. and R. Shine. 2002. Lying in wait for extinction: ecological correlates of conservation status among Australian elapid snakes. Conservation Biology 16: 451-461.

Saint-Girons, H. 1982. Reproductive cycles of male snakes and their relationships with climate and female reproductive cycles. Herpetologica 38: 5-16.

Sawaya, R. J. 2003. História natural e ecologia das serpentes de cerrado da região de Itirapina, SP. Unpublished Ph.D. Thesis. Universidade Estadual de Campinas, Brazil.

Seigel, R. A. and N. B. Ford. 1987. Reproductive ecology. Pp. 210-252, in R. A. Seigel, J. T. Collins and S. S. Novak (eds.), Snakes - Ecology and Evolutionary Biology. New York. McMillan Publishing Company.

Seigel, R. A., M. M. Huggins and N. B. Ford. 1987. Reduction in locomotor ability as a cost of reproduction in gravid snakes. Oecologia 73: 481-485.
Scrocchi, G. and M. Viñas. 1990. El género Clelia (Serpentes: Colubridae) em la República Argentina: revisión y comentarios. Bollettino del Museo Regionale di Scienze Naturali Torino 8: 487-499.

Shine, R. 1978. Growth rates and sexual maturation in six species of Australian elapid snakes. Herpetologica 34: 73-79.

Shine, R. 1979. Activity patterns in Australian elapid snakes (Squamata: Serpentes: Elapidae). Herpetologica 35: 1-11.

Shine, R. 1980a. Comparative ecology of three Australian snake species of the genus Cacophis (Serpentes, Colubridae). Copeia 1980: 831-838.

Shine, R. 1980b. "Costs" of reproduction in reptiles. Oecologia 1980: 92-100.

Shine, R. 1989. Constraints, allometry, and adaptation: food habits and reproductive biology of Australian brown snakes (Pseudonaja: Elapidae). Herpetologica 45: 195-207.

Shine, R. 2003. Reproductive strategies in snakes. Proceedings of the Royal Society of London 270: 9951004.

Slip, D. J. and R. Shine. 1988. The reproductive biology and mating system of diamond pythons, Morelia spilota (Serpentes: Boidae). Herpetologica 44: 396404.

Strussmann, C. 1992. Serpentes do Pantanal de Poconé, Mato Grosso: composição faunística, história natural e ecologia comparada. Unpublished M.Sc. Dissertation. Universidade Estadual de Campinas, Brazil.

Teixeira, R. L. and D. Vrcibradic. 2003. Clelia plumbea (Mussurana). Necrophagy. Herpetological Review 34: 248.

Vinegar, A. 1977. Evolutionary implications of temperature induced anomalies of development on snake embryos. Herpetologica 30: 72-74.

Vitt, L. J. 1983. Ecology of an anuran-eating guild of terrestrial tropical snakes. Herpetologica 39: 52-66.

Vitt, L. J. 1987. Communities. Pp 335-365, in R. A. Seigel, J. T. Collins and S. S. Novak (eds.), Snakes Ecology and Evolutionary Biology. New York. McMillan Publishing Company.

Vitt, L. J. and L. D. Vangilder. 1983. Ecology of snake community in the northeastern Brazil. AmphibiaReptilia 4: 273-296.

Volsøe, H. 1944. Seasonal variation of the male reproductive organs of Vipera berus (L.). Spolia Zoologica Musei Hauniensis 5: 1-157.

Zaher, H. 1994. Phylogenie des pseudoboini et evolution des Xenodontinae sud-americains (Serpentes, Colubridae). Upublished Ph.D. Thesis. Musée National D’Histoire Naturelle, Paris. 
Zaher, H. 1996. A new genus and species of Peseudoboinae snake, with a revision of the genus Clelia (Serpentes, Xenodontinae). Bollettino del Museo Regionale di Scienze Naturali Torino 14: 289-337.

Webb, J. K., B. W. Book and R. Shine. 2002. What makes a species vulnerable to extinction? Comparative lifehistory traits of two sympatric snakes. Ecological Research 17: 59-67

Zar, J. H. 1999. Biostatistical Analysis. $4^{\text {th }}$ ed. New Jersey. Prentice Hall. 